\title{
The influence of honey harvest conditions on the production of the royal jelly by queen bees
}

\author{
Mishchenko O.A ${ }^{1}$., Lytvynenko O.M ${ }^{2}$., Afara K.D ${ }^{3}$., Kryvoruchko D.I . \\ ${ }^{1-3}$ NSC «P.I. Prokopovich Institute of beekeeping» \\ 19, Akademika Zabolotnoho Str., Kyiv, 03143, Ukraine \\ ${ }^{4}$ National University of Life and Environmental Sciences of Ukraine \\ 16, Polkovnyka Potiekhina Str., Kyiv, 03041, Ukraine \\ e-mail: ${ }^{1}$ honey72@i.ua*, ${ }^{2}$ alesyasandra@ukr.net, ${ }^{4}$ dimokmpx@ukr.net \\ ORCID: ${ }^{1}$ 0000-0001-9970-8540, ${ }^{2} 0000-0001-6643-2285,{ }^{4} 0000-0003-1788-6090$
}

\begin{abstract}
Goal. To study the biological potential for the production of the royal jelly by bees in the conditions of supportive and intensive honey harvest. Methods. Laboratory - for the determination of royal jelly mass, zootechnical for the accounting the number of queen larvae in the bee families, ethological - for the determination of the orientation of bees in the area near the hive hole, and statistical - for biometric processing of experimental data. For the first time in the production of beekeeping products, a comparative analysis of obtaining the royal jelly was made for maintaining an intensive honey harvest. The production of the royal jelly was based on the technological process of artificial growth of the queens, which is interrupted after 72 hours after grafting larvae. Families for the reception of larvae were formed by a method of incomplete desertion. Incomplete desertion of the bee family meant that the bee queen was not completely isolated from a bee family. For that purpose, the bee family was divided in half with a solid diaphragm with the Hahnemann lattice, which isolated the queen bee. For the flight of the bees-collectors of nectar and bee pollen, only the entrance in the section with the queen bee was left open. In the research process, they applied the method of the use of bee families for producing the royal jelly simultaneously with the collection of nectar and pollen by bees in conditions of relatively small supportive and intensive honey harvest. Results. The technological method of formation and use of families-growers during the obtaining the royal jelly, which significantly reduced labor costs and funds for its production has been developed and tested. Conclusions. In the conditions of supporting honey harvest, the positive effect of bringing nectar to the reception of larvae in the nests of families was revealed. In various types of honey harvest (maintenance and intensive) for the production of royal jelly using the method of incomplete desertion, it is possible to use bee families of Ukrainian and Carpathian breeds. It was a slight advantage of the bee families of the Ukrainian steppe breed over the bee families of the Carpathian breed for the production of royal jelly.
\end{abstract}

Key words: bee family, bowl, Nicot system, intense honey harvest, supporting honey harvest.

DOI: https://doi.org/10.31073/agrovisnyk202104-06

Ukraine is one of the leading countries in the world with developed beekeeping. Successful development of beekeeping and increase of its productivity in the area of intensive management of agricultural production depends on several factors among which the availability of the different species of meliferous plants and their efficient use by bees are of paramount importance [1-3].

Honey bee (Apismellifera L.) is the most common species of genus Apis living on the territory of Ukraine. The variety of landscapes and climatic conditions provides extensive conditions for its reproduction and breeding. The adaptive potential allowing to live in the areas with high variability of climatic conditions and use of honey collection is of great importance for the creation of the wide range of honey bees.

In the conditions of fodder base for bees in Kyiv region the intensive use of available biological potential of bee families is possible not only in the production of honey and wax, but also in obtaining of additional beekeeping products which include royal jelly.

Royal jelly is the biologically active beekeeping product[4]. Royal jelly is produced by young nurse bees from age 4-6 to 12-15 that take care of larva. The majority of researchers believe that royal jelly is secreted by trophic glands: hypopharyngeal and mandibular $[4,5]$.It is estimated that protein fraction of royal jelly are mainly produced in hypopharyngeal glands, lipid - in mandibular, carbohydrates and pollen are received from honey stomach[5, 6]. Pollen is found in royal jelly In small quantities.

The development of modern technologies of producing of beekeeping products, including royal jelly, is one of the actual problems of modern beekeeping [7-10].

The technology of obtaining the royal jelly is based on the ability of bee families left without queen bee to form queen cells for rearing the new one. Providing bee families with the required amount of food is the important component of this technology. Feed resources of bees include honey and bee pollen that are consumed by worker bees and also by young non-flying bees and larvae on distinct stages of complete metamorphosis (holometabolism). It has been determined that in consumption of honey only, bees accept much less number of larvae for rearing, the amount of royal jelly decreases and in case of use of bee pollen as food its protein substances are used for development of hypopharyngeal glands and royal jelly can be received from bee families. $[5,10]$. When these components are available in the bee nest and environment (constant flow), the bee family is capable of producing the royal jelly on an industrial scale [11].

The production of royal jelly and producing the treatment and preventive remedies, diet compositions and cosmetic forms on its basis is one of the factors of increased profitability of beekeeping[12-15]. 
Goal To study the biological potential of producing the royal jelly by bees under supportive and intensive honey collection.

Materials and methods of research: the research was conducted on the base of experimental apiary of National Scientific center "Institute of beekeeping named after P.I. Prokopovich" and in the conditions of nomadic apiary on the standard bee families of Ukrainian steppe breed (Apismelliferasossimai) and Carpathian breed (Apismelliferacarpatica). The bee families met the conditions of the standard of Ukrainian steppe breed and Carpathian breed, as confirmed by the results of the exterior evaluation.

The group of bee families for the research were created by bringing the queen bees from the breeding bee apiary in the zone of their purebred breeding: Carpathian breed- from the apiary of Vuchkove (Zakarpatska Oblast), Ukrainian steppe breed - was bred on the base of experimental apiary. Caring for the bee families of the research groups was conducted in the same way, according to the generally accepted methodologies [16].

The selection of the queen-rearing colonies was conducted by the following criteria: the power of the family $3,0 \mathrm{~kg}$, fodder base $-10 \mathrm{~kg}$ of honey and two frames of bee bread, at least 7-8 frames of the brood of different age, the age of queen bee -2 years. The equal conditions for caring and development were created for all the bee families. The long hives for the standard frame measuring $435 \times 300 \mathrm{~mm}$ were used. The producing of royal jelly was based on technological process of the artificial rearing of queen bees that was interrupted 72 hours after grafting of larva (larval transfer).

Queen-rearing colonies intended for the reception of larvae were formed using the method of incomplete (partial) adoption [17]. In accordance with the method of incomplete (partial) adoption the queen bee was not completely isolated from the bee family. For this purpose the bee family was divided into two using solid diaphragm into which the unit of the Hahnemann lattice was installed and in this way the queen bee was isolated. For the flight of the bees collecting nectar and bee pollen only the entrance in the section with queen bee was left open.

Into the formed by diaphragm queen-rearing colony, into the beforehand prepared «wells» (empty spaces between the frames with brood of different age and frames without the brood)two grafting frames were sequentially placed. On the grafting frames with three longitudinal bars 60 artificial cell cups were glued using melted wax at a distance of $3 \mathrm{~cm}$ from one another. Before grafting the larvae, the frame with cell cups was placed in to the nest so bees could clean and become familiar with them. Into the frame prepared this way the larvae not older than 24 hours was transferred using spatula. For obtaining the larvae the revision of the few bee families was conducted beforehand to define which one of them contains the brood of suitable age. The following conditions were maintained: temperature of the air $25-28{ }^{\circ} \mathrm{C}$, relative humidity $80-90 \%$.After the grafting the two frames with larvae were transferred into the queen-rearing colony. In a day after the grafting we checked if families accepted the larvae and three days later the grafting frames with larvae were replaced by another ones. The bees were swept away from the selected grafting frames with larvae and royal jelly, then the frames were placed into the portable box and transported to the laboratory facility where the tops of the queen cells were cut off using the hot knife almost above the level of royal jelly and the larvae was removed using the spatula. For the obtaining of royal jelly from the queen cells the special glass spatula was used. According to the conditions of research, the sealed and open brood was taken from the section with queen bee and transferred into the queen-rearing colony throughout the period of obtaining the royal jelly. The removed frames were replaced with constructed honeycombs and honeycombs with comb foundation.

The duration of there search was34 days with 6 cycles of collecting the royal jelly. In total, 720 larvae of age 24-hours were grafted.

Biometric data processing was conducted on PC with the help of MS Excel software with the use of built-in statistical functions.

Research results. Weather conditions, namely the temperature of the air and precipitation had a significant impact on the growth of the control hive during our research. This is clearly seen on the diagram (Fig. 1) both through the period of supportive (May 31 - June 17) and intensive (main) honey collection (June 18 - July 5). During the rainfalls and drop in the temperature the decrease of growth in the control hive was observed.

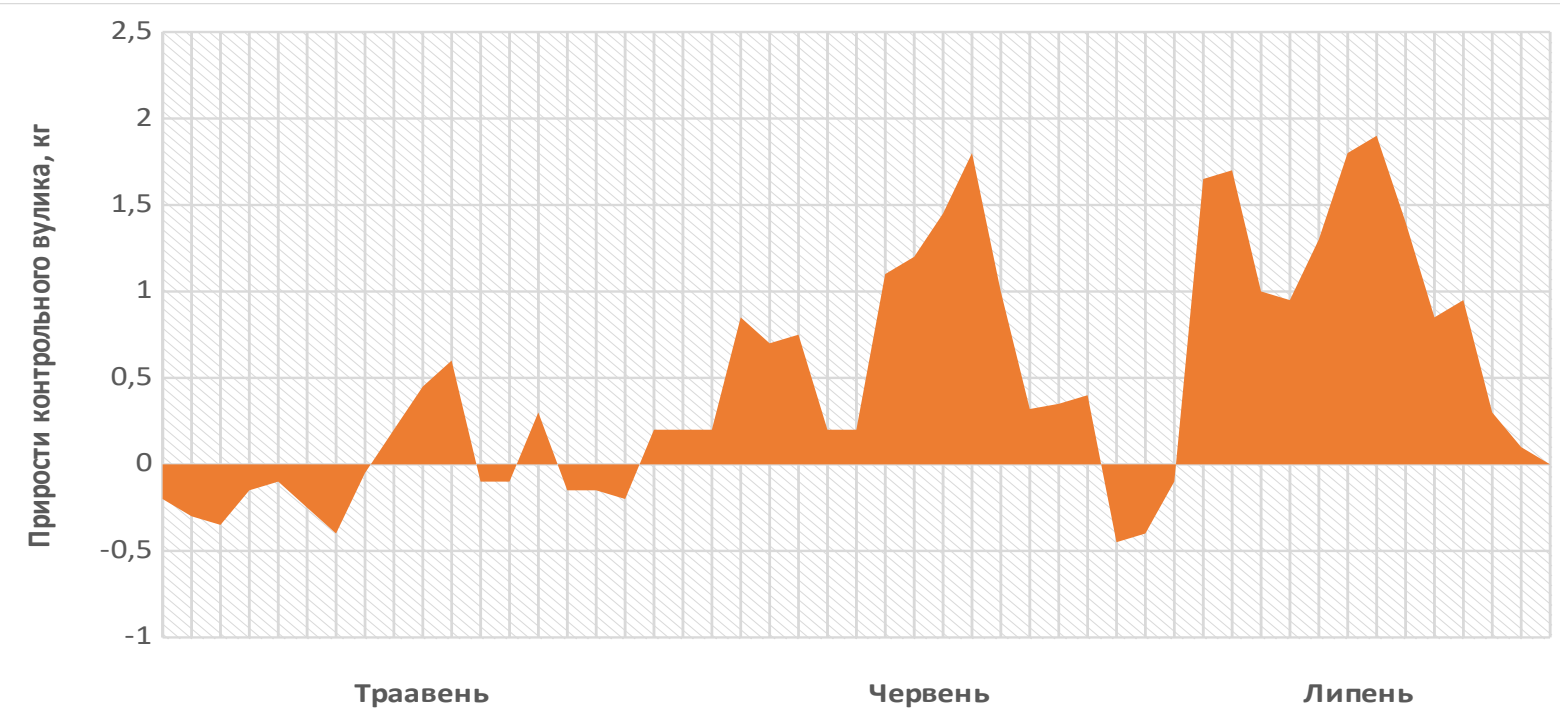

Fig. 1. The rate of the control hive during the period of intensive and and supportive honey collection 
The analysis of the rate of growth in the control hive during the period of supportive and main honey collection is mixed. The maximal value of flow was observed on June $23-1,8 \mathrm{~kg}$. On the other days the flow of nectar fluctuated from $0,085 \mathrm{~kg}$ to $1,45 \mathrm{~kg}$, starting from June 25 it began to decrease and then stopped.

Comparing the dynamics of adopting the larvae by bee families during the two periods of there search it is worth noting that adopting the larvae hile using the technology off forming queen-rearing colonies with incomplete (partial) adoption during the supportive honey collection, namely $0,085-0,75 \mathrm{~kg}$ of nectar was, on average on the level 43,2 larvae in the group of families of Ukrainian steppe breed and 46,5 larvae in the group of families of Carpathian breed.

1. Number of larvae adopted by queen-rearing colonies with incomplete (partial) adoption, $n=10, M \pm m$

\begin{tabular}{|c|c|c|c|c|c|c|}
\hline \multirow{3}{*}{$\begin{array}{l}\text { The date of } \\
\text { grafting the } \\
\text { larvae }\end{array}$} & \multicolumn{6}{|c|}{ The breed of bees } \\
\hline & \multicolumn{3}{|c|}{ Ukrainian steppe } & \multicolumn{3}{|c|}{ Carpathian } \\
\hline & $M \pm m$ & $\lim$ & $\mathrm{Cv}, \%$ & $\mathrm{M} \pm \mathrm{m}$ & $\lim$ & $\mathrm{Cv}, \%$ \\
\hline \multicolumn{7}{|c|}{ Supportive honey collection } \\
\hline 31.05 & $39,7 \pm 2,54$ & $28-42$ & 14,5 & $40,7 \pm 5,42^{*}$ & $33-47$ & 21,1 \\
\hline 3.06 & $43,8 \pm 3,12$ & $35-48$ & 10,1 & $50,6 \pm 5,53^{*}$ & $39-56$ & 23,5 \\
\hline 6.06 & $46,2 \pm 3,10$ & $30-54$ & 42,2 & $44,9 \pm 3,04$ & $30-51$ & 27,4 \\
\hline 9.06 & $44,3 \pm 2,04$ & $36-55$ & 28,7 & $50,4 \pm 4,88$ & $43-55$ & 24,2 \\
\hline 12.06 & $43,5 \pm 2,47$ & $41-52$ & 9,5 & $46,7 \pm 2,78$ & $25-51$ & 8,2 \\
\hline 15.06 & $41,7 \pm 1,72$ & $35-46$ & 15,8 & $45,5 \pm 3,11$ & $36-48$ & 7,1 \\
\hline \multicolumn{7}{|c|}{ Intensive honey collection } \\
\hline 17.06 & $38,8 \pm 5,06$ & $24-43$ & 13,9 & $40,9 \pm 2,75$ & $27-45$ & 13,8 \\
\hline 20.06 & $41,7 \pm 3,08$ & $37-56$ & 16,3 & $54,8 \pm 2,18$ & $38-57$ & 12,5 \\
\hline 23.06 & $42,9 \pm 2,23$ & $35-53$ & 12,7 & $48,9 \pm 5,87$ & $35-54$ & 36,5 \\
\hline 26.06 & $40,8 \pm 2,45$ & $32-47$ & 18,5 & $43,7 \pm 1,67$ & $36-50$ & 15,7 \\
\hline 29.06 & $40,7 \pm 2,43$ & $21-44$ & 17,8 & $40,6 \pm 2,06$ & $30-52$ & 11,4 \\
\hline 2.07 & $39,8 \pm 1,57$ & $26-45$ & 11,3 & $45,9 \pm 2,18$ & $37-55$ & 14,4 \\
\hline
\end{tabular}

Note. $p \leq 0,01 ; p \leq 0,05$ comparing with group of bees of Ukrainian steppe breed.

During the intensive honey collection with the flow of 0,32-1,8 $\mathrm{kg}$ of nectar the adopting of larvae in the group of queen-rearing colonies of Carpathian breed which produced royal jelly was on the level of 45,8 larvae, Ukrainian steppe breed- 40,8 larvae (table 1).

During the production examination a series of studies was conducted focused on the in fluence of the supportive and intensive honey collection on the producing of royal jelly by bees. The quantity of the royal jelly collected through the period of research (May 31 - July 5) is slightly different in groups. The available data suggest that under the conditions of supportive honey collection from group of queen-rearing colonies of Ukrainian steppe breed only $37,5 \pm 2,71 \mathrm{~g}$ of royal jelly was obtainedont heaver age, and from the group of colonies of Ukrainian steppe breed $-35,4 \pm 1,02$ (Fig. 2).

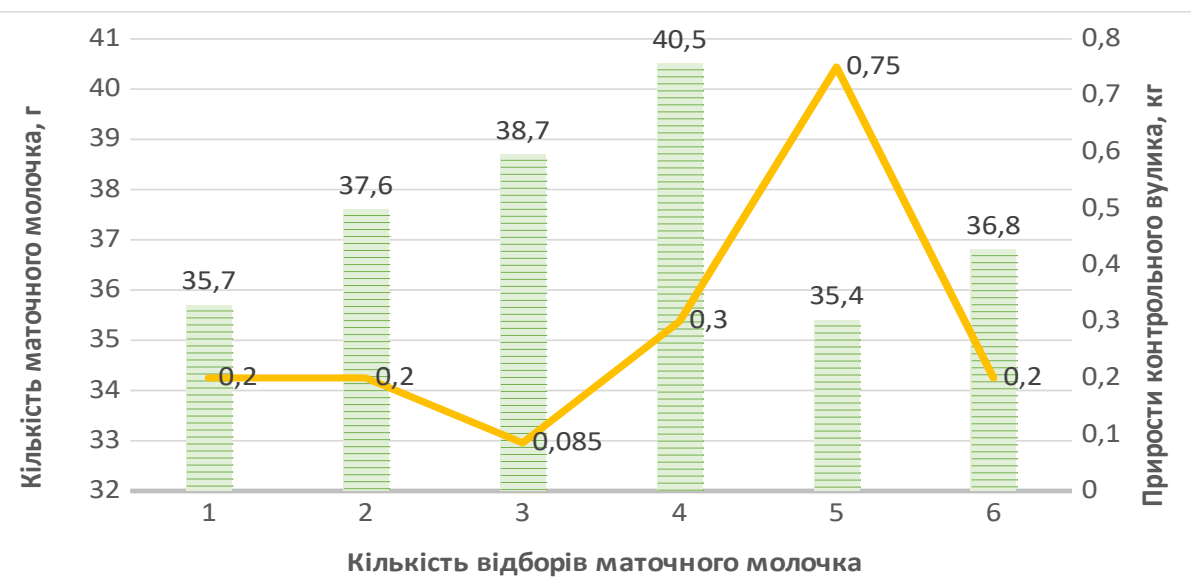

Маточне молочко Нектар

Fig. 2. Production of royal jelly by bees of Ukrainian steppe breed under the conditions of supportive honey collection, $g, n=10$

A different picture emerged while serving intensive honey collection: a total of $33,2 \pm 1,01 \mathrm{~g}$ was received from queen-rearing colonies of Ukrainian steppe breed, correspondingly from the group of colonies of Carpathian breed- $28,8 \pm 2,71 \mathrm{~g}$ (Fig. 3). 


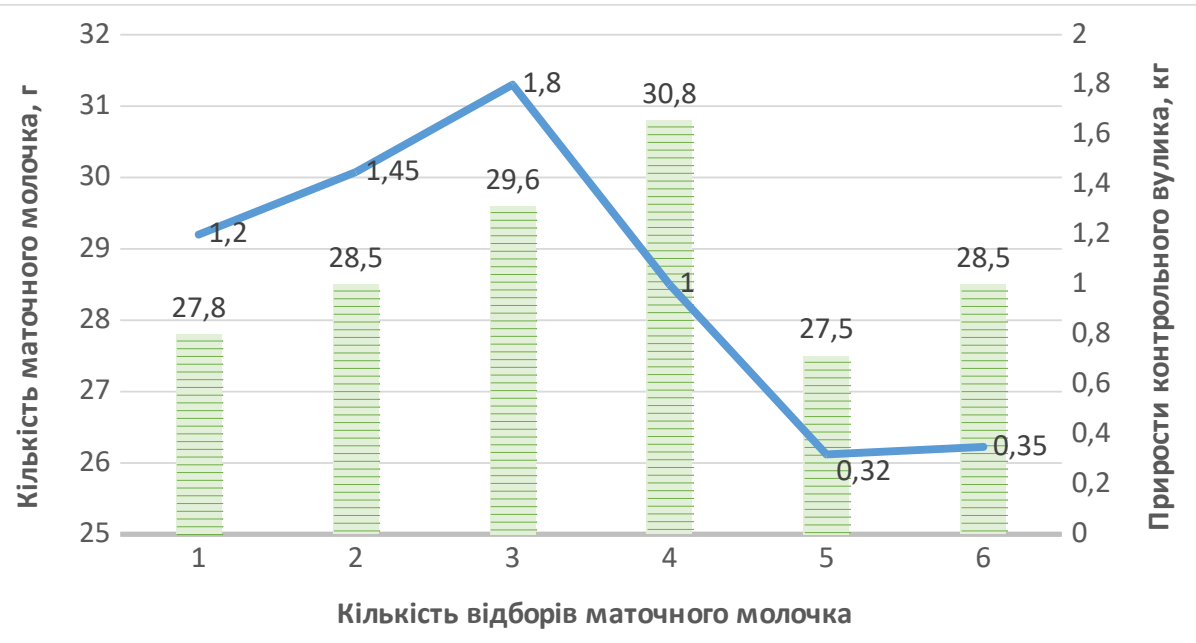

Маточне молочко

Fig. 3. Production of royal jelly by bees of Ukrainian steppe breed under the conditions of supportive honey collection, $g, n=10$

The largest quantity of royal jelly in one queen cell was observed during the period of supportive honey collection. Under the supportive honey collection with the flow of the nectar into the nest, starting from 1-1,3 kg, the bees mobilized more for the harvesting of carbohydrate food and the reliable decrease in production of royal jelly was observed $(p \leq 0,001)$, (table 2$)$.

2. Dynamics of the mass of royal jelly in queen cells under the conditions of different types of honey collection, $\mathrm{mg}$

\begin{tabular}{|c|c|c|c|l|c|c|l|}
\hline Tyoes of honey collection & $\mathrm{n}$ & \multicolumn{6}{|c|}{ Mass of royal jelly in one queen cell, $\mathrm{mg}$} \\
\cline { 3 - 8 } & & $\mathrm{M} \pm \mathrm{m}$ & $\min$ & $\max$ & $\mathrm{M} \pm \mathrm{m}$ & $\min$ & $\max$ \\
\hline $\begin{array}{c}\text { Supportive (May 31- } \\
\text { June 17) }\end{array}$ & 20 & $0,245 \pm 0,02$ & 0,170 & $0,260 \pm 0,02$ & 0,238 & 0,164 & 0,244 \\
\hline $\begin{array}{c}\text { Intensive (June 18-July } \\
\text { 5) }\end{array}$ & 25 & $0,230 \pm 0,01$ & 0,175 & $0,248 \pm 0,01$ & 0,218 & 0,115 & 0,230 \\
\hline
\end{tabular}

This difference is due to the decrease of putting the royal jelly in to the queen cells and lower rate of adopting the larvae. According to the data in table 2, the difference between the filling of the queen cells with jelly is insignificant. Until the end of the research period the nurse bees gradually decreased the filling of queen cells. The quantity of the royal jelly during the collection from colonies of Ukrainian steppe breed stood at $0,237 \mathrm{~g}$ and in the group of Carpathian breed - 0,228 $\mathrm{g}$ which is $3,95 \%$ less.

\section{Conclusions}

The comparative analyses of obtaining the royal jelly under the conditions of supportive and intensive honey collection was conducted.

It was established that:

1. There is an inverserelationship between the flow of the nectarin to the beefamily (the rate of the control hive) and adopted larvae. During the supportive honey collection the positive impact of the nectar flow on the adopting the larvae in the nests was identified.

2. Duringtheintensivehoneycollectiontheinverserelationshipbetweentherateofcontrolhiveandadopte dlarvaewasdefined.

3. With the flow of the nectarine to the nest starting from 1-1,3 $\mathrm{kg}$, the beesare more mobilized for the harvesting of the carbohydratefoodandthedecreaseofadoptingthelarvaeandproduction of royal jelly under the intensive honey collection was observed.

4. Under different types of honey collection (supportive and intensive) for producing of royal jelly using the method of incomplete (partial) adoption it is possible to use bee families of Ukrainian and Carpathian breeds.

5. The slight advantage of bees of Ukrainian steppe breed over bees of Carpathian breed regarding the producing of royal jelly was identified (3,95\% less).

\section{References}

1. Moskaliuk, I.V., Sakun, M.M., \& Khamid, K.O. (2018). 1. Moskaliuk I.V., Sakun M.M., Khamid K.O. Analiz stanu haluzi bdzhilnytstva Ukrainy, osoblyvosti orhanizatsii okhorony pratsi ta udoskonalennia pravyl bezpeky z bdzholamy [Analysis state of the beekeeping industry of Ukraine, features organization of labor protection and improvement of security fork with bees]. Science Rise, 4, 10 - 13. doi: 10.15587/2313-8416.2018.129317 
2. Kovalskyi, Yu.V., \& Kovalskaia, L.N. (2016). Osobennosty razvedenyia karpatskykh pchelFeatures of breeding Carpathian bees. Scientific Bulletin of Lviv National University of Veterinary Medicine and Biotechnology S.Z. Gzhytsky, 18 (65), 60 - 64.

3. Kryvda, M. (2018). Development of apiculture in the Zhytomyr region. Scientific Messenger of LNU of Veterinary Medicine and Biotechnologies. Series: Veterinary Sciences, 20(83), 208-211. doi: 10.15421/nvlvet8340

4. Kanelis, D., Tananaki, C., Liolios, V. et al. (2015). A suggestion for royal jelly specifications. Prijedlog globalnih standarda za matičnu mliječ. Archives of Industrial Hygiene and Toxicology, 66(4), 275 - 284. doi: 10.1515/aint-2015-66-2651

5. Ahmad, S., Campos, M., Fratini, F. et al. (2020). New Insights into the Biological and Pharmaceutical Properties of Royal Jelly. International Journal of Molecular Sciences, 21, 1-28. doi: 10.3390/ijms21020382.

6. Han Hu, Gebreamlak Bezabin, Mao Feng et al. (2019). New Insights into the Biological and Pharmaceutical Properties of Royal Jelly. International J. of Molecular Sciences, 18, 606 - 621. doi:10.1074/ mcp.RA118.001257

7. Brandorf, A.Z., \& Ivoilova, M.M. (2018). The influence of environmental factors on the quality standards of royal jelly Apis mellifera L. Agricultural Science Euro-North-East, 62 (1), 19-26. doi: 10.30766/20729081.2018.62.1.19-26

8. Li, Jianke (2000). Technology for royal jelly production. American Bee Journal, 140, 469-472.

9. Chuan Ma, Licui Zhang, Mao Feng et al. (2020). Metabolic profiling unravels the effects of enhanced output and harvesting time on royal jelly quality. Food Research International, 139, 109974. doi: 10.1016/j.foodres.2020.109974.

10. Altaye, Solomon Meng, \& Lifeng Li, Jianke (2019). Molecular insights into the enhanced performance of royal jelly secretion by a stock of honeybee (Apis mellifera ligustica) selected for increasing royal jelly production. Apidologie, 50, 436 - 453. doi: 50.10.1007/s13592-019-00656-1.

11. Pudasaini, Rameshwor Dhital, \& Bigya Chaudhary, Smiriti (2020). Nut-ritional requirement and its role on honeybee: a review. J. of Agriculture and Natural Resources, 3, 321-334. doi: 10.3126/janr.v3i2.32544.

12. Lin Y., Zhang M., Wang L. et al. (2020). The in vitro and in vivo wound-healing effects of royal jelly derived from Apis mellifera L. during blossom seasons of Castanea mollissima BI. and Brassica napus L. in South China exhibited distinct patterns. BMC Complementary Medicine and Therapies, 20, 1 - 13. doi: 10.1186/s12906-020-03138-5.

13. Duran, Yasin, Karaboga, Ihsan, Polat, Fatin et al. (2020). Royal jelly attenuates gastric mucosal injury in a rat ethanol-induced gastric injury model. Molecular Biology Reports, 47, 8867 - 8879. doi: 10.1007/s11033020-05939-w.

14. M. Ali, Amira \& Kunugi, Hiroshi (2020). Apitherapy for Parkinson's Disease: A Focus on the Effects of Propolis and Royal Jelly. Oxidative Medicine and Cellular Longevity, 9, 1 - 38. doi: 10.1155/2020/1727142.

15. Sabatini, A., Marcazzan G., Caboni, M. et al. (2009). Quality and standardization of Royal Jelly. Journal of ApiProduct and ApiMedical Science, 1, 1-6. doi: 10.3896/IBRA.4.01.1.04.

16. Borodachev, A.V., Burmistrov, A.N., Kasyanov, A.I. et al. (2006). Metody provedeniya nauchnoissledovatelskikh rabot $v$ pchelovodstve [Metody provedeniya nauchno-issledovatelskikh rabot $v$ pchelovodstve]. Rybnoe: NIIP, $4-11$.

17. Malkov, V.V., Martynov, A.G., Nazin, S.N. (1994). Vyvod pchelinykh matok: prakticheskoe rukovodstvo [Vyvod pchelinykh matok: prakticheskoe rukovodstvo]. Ryazan: Russkoe slovo. 